Article

\title{
Lean Energy: Turning Sustainable Development into Organizational Renewal
}

\author{
Árni Halldórsson ${ }^{1, * \mathbb{C}}$, Ida Gremyr ${ }^{1}$, Anette Winter ${ }^{2}$ and Naghmeh Taghahvi ${ }^{1}$ \\ 1 Division of Service Management \& Logistics, Chalmers University of Technology, 41296 Gothenburg, \\ Sweden; ida.gremyr@chalmers.se (I.G.); naghmeh.taghavi@chalmers.se (N.T.) \\ 2 Chalmers Professional Education, 41756 Gothenburg, Sweden; anette.winter@chalmers.se \\ * Correspondence: arni.halldorsson@chalmers.se; Tel.: +46-31-772-1000
}

Received: 2 October 2018; Accepted: 23 November 2018; Published: 28 November 2018

check for updates

\begin{abstract}
The potential for integrating principles of lean management and sustainability initiatives has been recognized in earlier research. The present study argues for the need to focus on how this should be implemented and to acknowledge the criticality of developing individuals' competencies to support such integration. The purpose of this paper is to explore the integration of lean and energy efficiency practices and provide practical examples of such integration. This study is explorative in nature and based on a qualitative research approach. Primary evidence was collected through an interview study of 19 participants in a lean energy course, and through a participant observation at a company workshop following up the program results. Secondary evidence was collected on the development and evaluation of this course. By operationalizing sustainability through energy efficiency and combining with lean principles, organizations can exploit continuous improvement efforts for sustainable development. This paper focuses on professional education as a component for integrating improvement initiatives and sustainable development. Whilst professional education enables individual learning, organization-wide efforts are needed to follow up on the educational program and support a scaling-up of lean energy. The scaling-up means that the organization itself encourages the use of principles and tools to identify and remove energy waste and support a move from local practices to shared experience.
\end{abstract}

Keywords: lean; energy efficiency improvement; continuous improvement; sustainable development; professional education; organizational renewal

\section{Introduction}

Operations processes in a variety of sectors, such as manufacturing, processing, and logistics, are powered by energy. For these processes, efficient and effective use of energy is one of the most immediate actions towards sustainable development, decreased emission, improved resource utilization, and the transition to renewable energy. Hence, improvements supporting energy efficiency are beneficial for sustainability. In organizations, foundations for continuous improvement of operations are found in management principles and practices such as quality management and lean management. When conceptually integrated [1] with energy efficiency improvements, these fields create a promising pathway to sustainable development in that economic and environmental benefits are combined in a distinct manner. A growing number of organizations are focusing on energy efficiency as means of sustainable development of their operations [2]. To achieve this, organizations benefit from existing improvement principles and practices. The present paper presents a perspective on such an integrative effort through the conception of lean energy.

Recent literature has acknowledged the potential benefits of combining quality management and sustainability [3] and lean and green $[2,4,5]$. To achieve the effects of lean and green, they must 
be implemented simultaneously rather than sequentially $[4,6]$. However, although literature has reported on a range of achievements from lean and green initiatives [2,4], fewer attempts have been made to merge the fundaments and principles these provide [4]. The present paper builds on lean management as means of improving sustainable business practices and operations processes and focuses on energy efficiency initiatives as part of organizations' sustainable development efforts in general, and educational initiatives in particular. Against this background, the purpose of the paper is to explore the integration of lean and energy efficiency practices, and to provide practical examples of such integration.

This paper presents one way of operationalizing sustainable development by focusing on energy efficiency as the focal point of improvement, and by combining it with the principles of lean. In addition to this combination, the key contribution of this paper is its focus on professional education of the individual as one enabler for combining lean with energy efficiency initiatives, and the recognition of organizational effort to scale-up the application and to release a wider potential. The remainder of the paper is organized as follows. The next section presents the conceptual underpinnings of our approach to sustainable development, followed by a methods section and a section that presents the findings. The paper ends with a discussion and conclusions, including limitations as well as implications for research and practice.

\section{Literature and Conceptual Approach}

Previous research has widely acknowledged the role of quality management as a way of integrating sustainability in daily practices [3]. There has also been research advocating the potential of integrating sustainability and lean initiatives [7]. This section provides an overview of these two areas and then conceptualizes lean energy.

\subsection{Quality Management as a Basis for Sustainability Improvement}

Robèrt et al. [8] distinguished between sustainability in terms of principles and sustainable development as a process that entails a transition leading to "a certain favorable outcome" (p. 198). To achieve this, sustainable development can benefit from its conceptual complementarity of the improvement principles that lean entails. In particular, lean can be used as a catalyst for specific environmental sustainability practices such as pollution prevention practices [9] by looking at operators working in the processes that consume energy. This allows companies to use resources efficiently through less costly processes while maintaining standards for workers' well-being [10]. One way to integrate sustainability in organizations' daily practices is by integrating it into existing work practices and tools such as quality management as well as other improvement initiatives [5,11-13]. Siva et al. [3] identified four areas that have been in focus in research studying integration between quality management and sustainability: (1) integration of management systems for quality and for environmental sustainability; (2) use of quality management experiences to support implementation of environmental management systems; (3) support for integration of sustainability considerations in daily work; and (4) support in the areas of stakeholder management and customer focus.

The present paper departs from two of the areas identified by Siva et al. [3], namely quality management experience and integration in daily work, in order to explore the potential for integrating lean and energy efficiency practices. Quality management is here seen as an approach based on the principles of customer focus, continuous improvement, and teamwork, all supported by practices and tools [14]. Similar to this, lean offers an integrative approach to continuous improvement of operations processes. Lean is an operations strategy that focuses on improvements and prioritizes flow efficiency over resource efficiency [15]. In a similar vein as quality management-when operationalized into principles, practices and tools [14] -lean is often supported in its application by principles such as people engagement [16] and continuous improvement [17]. These principles are, in turn, supported by practices related to areas such as waste removal $[18,19]$ and tools such as value stream mapping [20]. 


\subsection{Sustainable Development and Lean}

The move towards simultaneous improvement of sustainability performance and operational efficiency has been referred to as "lean and green" [7]. Examples of this synergistic relationships between environmental and operational performance include waste reduction, lead time reduction, product design, people and organizations, and supply chain relations [4,21,22], as well as improving supply monitoring, transparency, workforce treatment, and community engagement [23,24]. These synergies suggest that lean practices can help companies to become greener and improve operational performance. Despite attempts to approach these synergies through "environmental innovation" aiming to transform a production system into a lean system (improving both operational and sustainable performance) [25], research on approaches helping managers to integrate lean and green in practice is still limited [7,21]. Lean and green are not easy to implement simultaneously [25] and calls have been made for new management models [26] as well as further conceptual understanding [4,7].

Abreu et al. [7] observed that eco-efficiency is a translation of "creating more with less". In line with this, lean has proved to be a well-suited approach in improving energy efficiency of operations. Practices such as waste reduction, pollution prevention, and energy efficiency can be improved through methods such as $5 S$ and value stream mapping, which are used to reduce waste and to improve energy efficiency through means such as better use of space, lead-time reduction, reusing heat, and aligning energy usage (for example, uptime of machines, lighting, heating) with flow principles of lean [2,4]. Moreover, it has been argued that employee involvement and quality circles stimulate new ideas to improve environmental sustainability [2]. This points to the need to focus not only on supportive tools but also on the necessary implementation structures and the risk of "losing people potential" [22], with the latter often recognized as an eight waste in lean. Building upon the potential in people and the need for a well-planned implementation strategy, Verrier et al. [22] proposed a maturity model on the extent to which "lean and green" is integrated. Such models can be used to evaluate how well an organization has managed the integration of sustainability into daily operations [11]. A key enabler for such integration is a firmer focus on people and their skills [27], both "increased" [2] and "deeper" employee involvement [7], and other activities to overcome barriers to sustainability knowledge in the organization [28].

\subsection{Sustainable Development of Operations through Energy Efficiency}

Operations processes are reliant upon use of energy, either directly as a resource to produce output (such as operating machines) or indirectly to support facilities (for example, by heating, ventilation, and lighting) [29]. Therefore, energy efficiency as a unit of resource consumption and cost of operational processes $[30,31]$ connects directly to both economic and environmental sustainability performance.

A company's operations strategy translates corporate goals into operations' performance objectives through a sequence of structural and infrastructural decisions made within the operations function [32]. Hence, the way in which operations processes are configured in terms of speed, flexibility, and so on shape the conditions for energy consumptions of these operations. This relationship, in turn, shapes the sustainability performance and eventually operational performance. Contemporary operations strategies that emphasize speed and flexibility have been designed and implemented in an industrial context where availability of energy has not been of great concern. However, extensive use of non-renewable energy sources, price, and security of energy sources have triggered a sense of urgency among policy makers, and academics and managers alike are encouraged to address energy efficiency in a more distinct manner than has hitherto been the case. Therefore, integrating energy efficiency into operations and considering energy efficiency simultaneously with other performance objectives in operations decision making is an important enabler for achieving sustainable operations. 


\subsection{Lean Energy}

While current literature reports on a range of initiatives that combine lean and green and relates various lean tools and approaches with energy efficiency improvements, it is less clear how organizations build up skills and competencies for such development. Harvesting the synergies of lean and green is "not simple" [5], and not all methods are available for a "prompt use" ([7], p. 852). Reverting to the fundamentals of quality management, such as continuous improvement and teamwork, people involvement is evident. Notably, in lean, the "maximum number of tasks and responsibilities" are transferred to those workers who actually add value to the product [20]. This engagement with skills at the manufacturing level in the organization is important in terms of influencing energy efficiency [33]. Recent literature has called for more attention to be paid to the sustainability skills and competencies of employees. One such response is through education, where universities collaborate with external stakeholders through teaching [34]. The "dynamic nature" of sustainability requires change of a teaching paradigm and development of social competencies ([34], p. 50), and more life-long learning in sustainability is called for to develop employee skills and promote people engagement $[26,35]$. Moreover, competences in sustainable development require a combination of different learning activities [36]. An important aspect of teaching programs is the collaboration between higher education and firms to promote concrete actions on sustainability [37].

To date, the conception of lean energy has been derived from the conceptual synergies between lean and sustainable development. Addressing sustainable development through energy efficiency shapes this study in at least three ways. First, energy efficiency creates a focus on the improvement initiatives; that is, reducing energy consumption of operations processes. Second, it promotes alignment of energy consuming activities with flow in operations processes, and vice versa. Rather than focus on sustainability as a particular condition or outcome, the present study follows Robèrt et al.'s [8] view on sustainable development as a process that leads to a favorable outcome. Therefore, a third shaping force that is considered is improvement efforts, which build upon the logic of quality management and lean regarding areas such as teamwork and empowerment, but extend the focus on matters such as waste reduction to include energy consumption. The conceptualization also identifies the need to develop personal skills and competencies and contributes to the limited research on how this development can take place. To further the understanding of how such development results in improvements we borrow from the literature on learning and organizational renewal. In doing so, we relate the different levels of renewal in our findings to the four sub-processes of organizational renewal by Crossan et al. [38] namely intuiting, interpreting, integrating, and institutionalizing.

\section{Method}

This study focuses on the potential in combining lean and energy efficiency and builds empirically upon the establishment of a professional education program, participants' experiences herein, and the organizational impact of such education. Given the explorative nature of the research, a qualitative research approach was taken [39]. In line with this and the need to be "sensitive to the context" [39], and provided that theory on the combination of lean and energy efficiency is "nascent" [40], the data collected was open-ended. Accordingly, primary evidence was collected through multiple sources of evidence; interview studies (face-to-face and phone) of participants that followed a lean energy education program (elaborated on in Section 4 below) and a participant observation. The organizations investigated operate in different sectors, including processing industry as well as the manufacturing and logistics sectors. In addition, secondary evidence was collected on the development and impact of the course program.

Data was collected over period of time, allowing participants to have an in-depth reflection upon their experience from the course as well as and impact of their learning on their organizations. The first stage of interviews was a post-program follow-up of the course itself, where nine participants from nine organizations were interviewed two years after completing the first cycle of the course. All interviewees work with energy efficiency improvements in their organizations. The fact that the 
participants in the professional education program belong to different organizational levels might have influenced their views on the impact of the program. The interviews focused on the interviewees' experiences with and perceived impact of the course, both on themselves and their organizations. The interview questions were structured around the following themes that also served as the foundation for data analysis: personal influence; knowledge and lessons learned; impact on their organization; barriers and drivers of change; and an overall assessment of the course.

The second round of interviews included 10 interviewees from 10 organizations from the second cycle of the course. Building upon the results of the first round and additional review of literature, these interviews followed a more structured approach to energy efficiency improvement in order to explore how the participants' organizations work with energy efficiency. At this stage, the participants answered a structured web-survey which was followed-up by individual in-depth interviews structured around the following themes: goal setting, identifying and funding opportunities, and implementation of solutions into specific processes. A third stage of data collection consisted of participant observation at a one-day workshop with participants from the course from one company in the processing industry. Two researchers from the group followed the presentations and the following discussions on both learning and the actual implementation initiatives associated with lean energy at multiple locations of the company. Notes were taken, and the description and synthesis of the day were sent to the company for validation.

Since the first two cycles of the course were organized as a 'pilot' and supported by a funding agency, much emphasis was placed on understanding, developing and documenting the learning opportunity for the participants, both during and after the course. This development and follow-up of the course entailed several iterations among the teaching staff, and resulted in documentation that was useful for this study in the form of minutes and reports from, for example, a steering committee and a review report to a funding agency. This evidence was included in the exploration of the impact of the course, in terms of personal learning, organizational development, and impact of the bottom line. Hence, secondary evidence in form of minutes from meetings and reports was used to provide further documentation of design process of the course and its content, as a well as on-going evaluation of the course based upon feedback from participants and a steering group consisting of internal and external stakeholders. This material can be summarized as being institutional prerequisites for the teaching program and included minutes from meetings on development of course syllabus, the course syllabus itself, reports to a funding agency and the steering group about the development, and results from the course. Using multiple sources of evidence allowed for a broader consideration how the education program was evaluated by different stakeholders, and served also as triangulation of data sources and methods [41].

The mode of the data analysis was characterized by pattern identification and pattern matching [41] around themes in the interview guide that can be regarded as core to quality management. Accordingly, results were regarded as being both at the individual and organizational levels. Furthermore, themes that emerged from the analysis at in the second interview round distinguished among people, perspectives, and practices. The sampling was based upon organizations participating in the education program, hence interviewing individuals that are responsible for energy efficiency initiatives in their organizations, and that are knowledgeable about the combination of lean and energy. Although the sample size may put some boundaries around the generalizability of the results it must be seen in relation to the opportunity of collecting data at three different points of time (two interview stages and a workshop). By doing this, the longitudinal nature of the research design is indented to capture organizational change process [42] that occurred as results of the education program. The preciseness or granularity [42] of the lean energy initiatives increased as more evidence was collected, and the data collection became more focused through the interview guide. 


\section{Findings}

The findings are presented in three overall categories: (1) a professional educational program as a means of combining lean and energy efficiency; (2) how the participants work with energy efficiency improvement (in relation to lean energy) - that is, the perceived impact the course program creates; and (3) organizational efforts needed for scaling up lean energy.

\subsection{Establishing the Principles: Lean and Energy Efficiency through Professional Education}

The lean energy professional education program is a combinatory effort of lean and energy and aims to develop skills and knowledge of individuals who are responsible for energy efficiency improvement in their organizations. The program is designed around five two-day modules delivered over a period of six months, focusing on topics ranging from general introduction to lean to energy technology and practices. Table 1 provides a summary of the program, presented here in terms of principles, practices, and tools to emphasize the improvement-based nature of the course.

Table 1. Lean Energy as a professional education—an overview.

\begin{tabular}{|c|c|c|c|}
\hline Module & Topics & Principles & Practices \\
\hline \multirow{3}{*}{1} & $\begin{array}{l}\text { Sustainable development, } \\
\text { introduction }\end{array}$ & History, principles & \\
\hline & Lean, introduction & Fundamental principles & $\begin{array}{l}\text { Lean game, } \\
\text { workshop }\end{array}$ \\
\hline & Energy efficiency & Fundamental principles & $\begin{array}{l}\text { Map current energy usage (home } \\
\text { assignment for next module) }\end{array}$ \\
\hline \multirow{4}{*}{2} & $\begin{array}{l}\text { Systems thinking and Life-Cycle } \\
\text { Assessment (LCA) }\end{array}$ & Theory on LCA & $\begin{array}{l}\text { Flowcharts of energy and material } \\
\text { flow and available resources }\end{array}$ \\
\hline & Energy and the environment & $\begin{array}{l}\text { Environmental effects of } \\
\text { various energy sources }\end{array}$ & \\
\hline & $\begin{array}{l}\text { Fundamentals in energy } \\
\text { technology }\end{array}$ & $\begin{array}{l}\text { Key concepts (energy effect } \\
\text { and } \mathrm{kWh} \text { ) and technology } \\
\text { (turbines, engines etc.) }\end{array}$ & \\
\hline & Energy mapping & & $\begin{array}{l}\text { Energy mapping (home } \\
\text { assignment for next module) }\end{array}$ \\
\hline \multirow[t]{2}{*}{3} & Key Performance Indicators (KPI) & $\begin{array}{l}\text { KPI of operations, connecting } \\
\text { lean and energy }\end{array}$ & $\begin{array}{l}\text { KPI and Value } \\
\text { Stream Mapping }\end{array}$ \\
\hline & Value stream mapping (VSM) & & $\begin{array}{l}\text { VSM theory and instructions } \\
\text { (home assignment for next } \\
\text { module-KPI \& VSM) }\end{array}$ \\
\hline \multirow{3}{*}{4} & Value stream mapping (VSM) & & $\begin{array}{l}\text { Presentation of VSM done in the } \\
\text { organization }\end{array}$ \\
\hline & Energy management systems & ISO50001 & \\
\hline & $\begin{array}{l}\text { Change management and } \\
\text { organizational culture }\end{array}$ & Fundamental principles & Change matrix \\
\hline 5 & $\begin{array}{l}\text { Future plans and actions in the } \\
\text { participants' organizations }\end{array}$ & \multicolumn{2}{|c|}{$\begin{array}{l}\text { Focus on presentation of each participants pilot project (throughout } \\
\text { the course) and plans for continuation and scaling up of the efforts }\end{array}$} \\
\hline
\end{tabular}

Each module included elements of the level of principles, practices, and tools. With the intention of having a direct impact on the participating organizations' work process and energy usage, the course was delivered with a combination of lectures, workshops, and home assignments. During the lectures, introductions to principles and tools alongside examples of application were given and the main part of the hands-on, practical training was carried out as home assignments between the modules. The assignments were introduced at the end of each module and presented and reflected upon in the subsequent module. Taking Module 3 as an example, two topics were introduced in the lectures: key performance indicators (KPIs) and value stream mapping (VSM, referred to as both tool 
and practice in Table 1). The bridge between the two topics was an illustration of how KPIs could serve as a support in VSM. Following the lectures, the participants were introduced to a home assignment on performing a VSM in their own organization and designing/using KPIs in relation to this.

\subsection{Perceived Impact of the Lean Energy Education Program}

As described in Table 1 above, the course provided a variety of learning activities in both lean and energy, individually and in combination. Table 2 below summarizes the results of the participants' view on the impact that the program had on themselves personally and wider lessons learned, including the impact on their organization. Whereas personal influence reflects on "ways of thinking", knowledge and lessons learned can be summarized as "ways of doing".

Table 2. Lean Energy as a professional education—depth of learning.

\begin{tabular}{|c|c|}
\hline Theme & Illustrative Indicators \\
\hline $\begin{array}{l}\text { Personal influence from the } \\
\text { course }\end{array}$ & $\begin{array}{l}\text { Firmer understanding of the key problem of sustainable development } \\
\text { Sense of urgency about environmental impact of operations and decisions } \\
\text { Enhanced personal engagement in the topic } \\
\text { More frequent use of lean as "lenses" to "find" waste and do something } \\
\text { about it }\end{array}$ \\
\hline $\begin{array}{l}\text { Knowledge and lessons } \\
\text { learned }\end{array}$ & $\begin{array}{l}\text { Understanding the environmental impact of operations was } \\
\text { thought-provoking } \\
\text { Use of value-stream mapping to analyze a production line from an energy } \\
\text { perspective } \\
\text { How to plan and organize energy efficiency improvement initiatives } \\
\text { Learning about and practicing change management } \\
\text { Mixture of participants }\end{array}$ \\
\hline Impact on organization & $\begin{array}{l}\text { Improved energy performance [mixed evidence] } \\
\text { Change management that leads to organizational development } \\
\text { Increased convergence with the company's other lean efforts } \\
\text { Easier to describe what can be changed }\end{array}$ \\
\hline
\end{tabular}

The first theme, personal influence, focuses on the participant as an individual. This refers to motivational factors such as creating a sense of urgency and personal engagement in the improvement work in their organization, such as recognizing the amount of energy consumption of their organizations and the ability to relate this to an impact on the natural environment. The second theme, knowledge and lessons learned, refers to rather subject-specific (that is, lean energy) aspects, including tools such as value-stream mapping. Analysis of production processes and to plan for improvement initiatives were mentioned as important lessons learned, as well as learning about and practicing change management. Although the mixture of participants from different organizations in the course was mentioned by the interviewees as beneficial, this did not lead to a wider comparison of practices cross organizations during the program period.

Finally, the interviewees were asked about the impact on the company's energy efficiency per se. The responses can be summarized into different types of impact: Improved energy efficiency and reduced energy consumption as measured in $\mathrm{kWh}$, for example. Other types of impact relate to the way of working with improvement efforts rather than directly to energy consumption; for example, creation of a joint vocabulary on lean and energy efficiency. Moreover, in organizations where 'lean' is common practice, such as in the manufacturing sector, working with lean energy became easier because it was possible to align energy efficiency in terms of both operational and environmental performance measures with established improvement initiatives. 


\subsection{Scaling up Lean Energy Practices: From Individual Learning to Organizational Development}

It became evident during the interviews that whilst lean energy offers potential in both direct and indirect influence on energy efficiency and improvement hereof, it also comes with challenges. Respondents argued that whilst the lean energy program presents relevant elements (cf. Table 1), the combination of these in practice is not an easy task, particularly if the participant is the only one from the organization following the program. More staff need to follow the same course program, not least from the management level to gain managers' engagement and support in the lean energy initiative. With only one or a few people pursuing lean energy in the organization, the implementation risks being limited to an area that does not exceed the responsibility of that individual. What is needed is a greater mandate to act, tools to stimulate further use and to visualize potential, and it also helps if economic benefits of the changes are immediate rather than long-term. Finally, it was mentioned that whilst understanding of lean and energy efficiency may be provided through education, good practical examples from different industries make integration into local practices easier.

Although the results indicate several benefits of the course program, the program's impact is primarily limited to the individual (personal learning) or to the organizational unit employing that individual. A few organizations have enrolled three or more people to the program. One company achieved critical mass to design and implement a small-scale improvement initiative through home assignments. Another organization that operates at multiple sites is pursuing a joint effort across its various locations; its approach was to let the individuals responsible for both energy efficiency and production improvement at the sites follow the course, but so did also a few senior members of the management team responsible for sustainable development in the company. In addition to home assignments presented at the course, this organization arranged a workshop with participants from various locations who had followed the course to present examples of improvement initiatives that built upon the principles of lean energy.

To illustrate the role of the organization to promote integration and dispersion of lean energy, we investigated the efforts of one organization that aimed to explore the unutilized potential amongst its own staff. The drivers for the organization were to develop the skills of its employees and give them more responsibility for their own working situation. Overall, the results suggest that this can be achieved through engaging a group of individuals in a course program, and by operating with improvement efforts simultaneously across different processes and/or locations. The results of this organization's initiative are presented in Table 3 under three headings: People, perspectives, and practices.

Table 3. Scaling up through people, perspectives, and practices.

\begin{tabular}{|c|c|c|}
\hline People & Perspectives & Practices \\
\hline Discovery and inclusion & $\begin{array}{l}\text { Visualize framework and tools } \\
\text { through "working model" }\end{array}$ & $\begin{array}{l}\text { From local practice to shared } \\
\text { experience }\end{array}$ \\
\hline $\begin{array}{ll}\text { - } & \text { Teamwork rather } \\
\text { than cowboys } \\
\text { - } & \text { Everyone becomes a } \\
\text { change agent } \\
\text { - } & \text { Hidden talent discovered } \\
\text { - } & \text { Individuals grow through } \\
\text { new roles } & \text { Support from line managers }\end{array}$ & $\begin{array}{ll}\text { - } & \text { Identify and remove waste } \\
\text { - } & \text { Train and educate employees }\end{array}$ & $\begin{array}{ll}\text { - } & \text { Promote a } \\
\text { "learning organization" } \\
\text { - } \quad \text { Synergies across locations } \\
\text { Integrate with other } \\
\text { improvement efforts in, } \\
\text { e.g., production } \\
\text { - } \quad \text { Strive for continuity }\end{array}$ \\
\hline
\end{tabular}

A sense of urgency is created through multiple sources, ranging from the organization's commitment to the EU's energy objectives (to decrease energy consumption) towards illustrating that energy costs constitute a significant share of the total variable costs of the company. Furthermore, the organization benefits from individual enthusiasm to improve both operational efficiency and 
environmental performance. The emphasis on people reflects achievement of a critical mass through more people taking part in the course and an "engaging" approach supported by, for example, teamwork and new roles and extended responsibilities given to individuals. Perspectives acknowledges the needs for more explicit knowledge that serves the dual purpose of improving operations and developing people skills. Finally, practices refer not only to "doing" things, but-perhaps more importantly - to continuous improvement efforts through learning and sharing. Here, employees responsible for lean energy noted that, in order to prosper, "we need to make it part of the everyday work" and that "continuity makes a difference".

In summary, the professional education investigated is based on a combinatory approach to lean and energy efficiency initiatives. The program design included a combination of learning approaches (lectures, practice, home assignments) to support in-depth learning. The program has been perceived to have personal influences, enhance individual knowledge, and to some extent impact performance at the organizational level. However, in order to scale-up and enhance the organizational impact, it appears beneficial to have a critical mass of program participants from the same organization followed by an organization-wide effort.

\section{Discussion}

The first contribution of the paper relates to the conceptual [1] and synergist relationship between lean and energy, which set out to explore the integration of lean and energy efficiency improvements, and practical examples of such combinations. The focal point of improvement was energy efficiency of operations processes in different industrial settings. The second, and perhaps more comprehensive, contribution relates to characteristics of lean energy that move towards advanced levels of learning. To further that understanding, we build upon the framework for organizational learning and renewal created by Crossan et al. [38]. The framework allows for exploration of three different levels of organizational learning and renewal recognized both from the lean literature and the empirical findings: Individual, group, and organization. In particular, the framework entails four sub-processes of learning and renewal that operate over these three levels: intuiting, interpreting, integrating, and institutionalizing. Relating the findings to these four processes furthers the exploration of integration of lean and energy efficiency practices, which can ultimately be depicted as a three-step progression towards organizational renewal through lean energy, as depicted in Figure 1: Through the conception of lean energy (Figure 1a), by building upon an out-side-in perspective on skill development through professional education (Figure 1b), and towards more established practice that requires what can be characterized as organizational scale-up (Figure 1c).

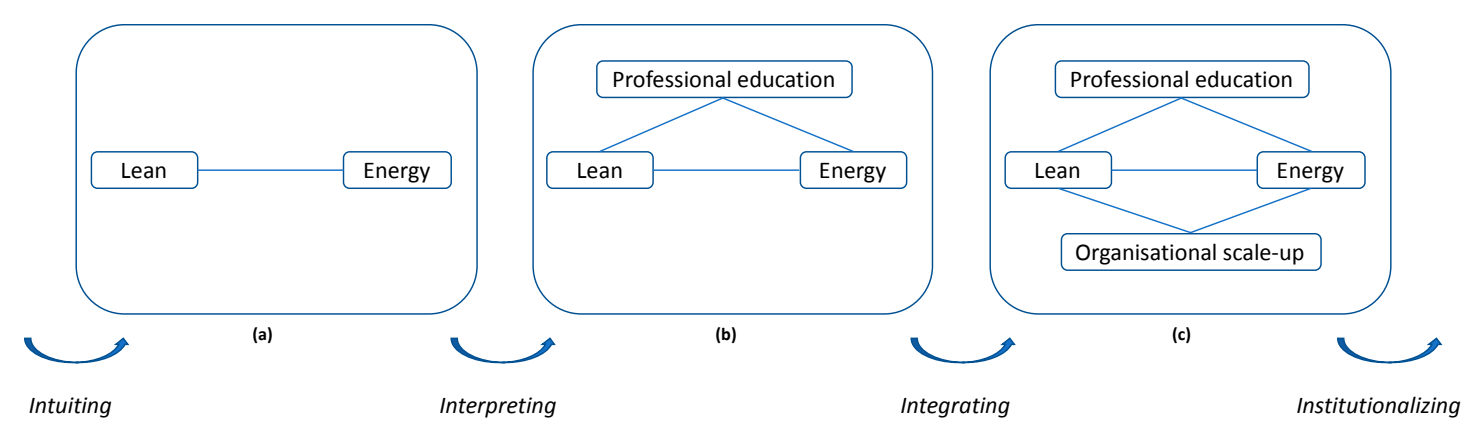

Figure 1. Lean Energy—progression from conception to organizational renewal.

Table 4 provides further details on how lean energy develops as the learning process becomes more advanced. 
Table 4. Four learning processes supporting lean energy as organizational renewal.

\begin{tabular}{|c|c|c|c|}
\hline Intuiting & Interpreting & Integrating & Institutionalizing \\
\hline $\begin{array}{c}\text { Experiences, Images, } \\
\text { Metaphors }\end{array}$ & $\begin{array}{c}\text { Language, } \\
\text { Cognitive map, } \\
\text { Conversation/dialogue }\end{array}$ & $\begin{array}{c}\text { Shared understandings } \\
\text { Mutual adjustment } \\
\text { Interactive systems }\end{array}$ & $\begin{array}{c}\text { Routines } \\
\text { Diagnostic systems } \\
\text { Rules and procedures }\end{array}$ \\
\hline Lean energy: & Lean energy: & Lean energy: & Lean energy: \\
\hline $\begin{array}{l}\text { Sense of urgency and } \\
\text { enhance personal } \\
\text { engagement } \\
\text { Initiate an intuition } \\
\text { process } \\
\text { Operationalize } \\
\text { sustainable development } \\
\text { Conceptual depth } \\
\text { Discover hidden talent }\end{array}$ & $\begin{array}{l}\text { Joint mindset and } \\
\text { vocabulary to, e.g., "find" } \\
\text { waste } \\
\text { Describe what is possible } \\
\text { to change } \\
\text { Connect to existing } \\
\text { improvement mindsets } \\
\text { Professional education }\end{array}$ & $\begin{array}{l}\text { Analyze production line } \\
\text { from an energy } \\
\text { perspective } \\
\text { Learn about change } \\
\text { management } \\
\text { Identify and remove } \\
\text { waste in a process } \\
\text { Lessons learned from } \\
\text { professional education }\end{array}$ & $\begin{array}{c}\text { Practice change } \\
\text { management } \\
\text { Everyone becomes a } \\
\text { change agent } \\
\text { Integrate across locations } \\
\text { through a "working } \\
\text { model" }\end{array}$ \\
\hline
\end{tabular}

\subsection{Intuiting}

Refers to outcomes such as experiences, images, and metaphors, and operating over the level of individual learning, it relates to developing insights and the comprehension of something new [38]. The act of combining lean and energy can be seen as an intuition process itself, creating a picture of possibilities through a new metaphor. Individuals start perceiving similarities and differences and their taken-for-granted view is forced to a more conscious level by combining lean energy with their own personal experience and operational context. Thus, intuiting corresponds well with the idea of discovering hidden talents and of engaging individuals that are close to the operational processes.

The findings confirm the potential of combining lean and green as current literature suggests [22] but simultaneously offers a distinct way of operationalizing sustainable development of operations through energy efficiency efforts. At this first level, lean energy refers to activities that can be implemented and effects defined in environmental and operational terms (Figure 1a above). The features of energy efficiency make it a viable object for improvement as it allows for consideration of both economic and environmental performance measures. By this, lean energy adds a conceptual depth to "green" (that is, environmental sustainability) by defining it in terms of energy consumption of operations processes, hence bringing responsibility for improvement to those who are close to the energy consuming processes [20] rather than a specialized unit in the company [13]. In summary, as depicted in Table 4 and Figure 1 above, when lean energy is seen as an intuiting process, it can be viewed as a means to initiate such a process. Through this intuiting process the first step towards operationalization of sustainable development takes place, in which a certain level of conceptual depth is required. At this stage, however, lean energy is vague and underdeveloped in terms of actions; it is 'what' to do or combine, but to a lesser extent 'how' to achieve integration of lean and energy efficiency practices.

\subsection{Interpreting}

Interpreting is a process through which an idea is explained, through words or actions, to oneself or others. Interpreting results in a change in an individual's understanding and actions [38]. Here, lean energy becomes verbal and individuals develop cognitive maps in which a joint mindset and vocabulary plays a central role. Lean comes with a set of concepts and certain assumptions underlying these, and terms such as "find waste" help individuals describe what is possible to change. As outlined above, lean energy as a professional education program provides insight into principles and application of, for example, value stream mapping to map energy usage, and to help individuals to create flowcharts. Hence, interpretation also takes place by connecting energy efficiency improvement to existing improvement efforts in other parts of the organization; that is, connecting with logics that are already known by others who work with quality management. 
Furthermore, in this process, professional education begins to play a role as a mechanism for learning. The findings that emphasize engagement of employees are also in line with the literature on lean [16] and the role of education in sustainable development [36]. However, the findings also illustrate how such competence development can benefit from participation in a professional education program in that participants can benefit by learning from peers, and their organization is likely to speed up the competence development by such external acquisition of knowledge [43].

Finally, interpretation relates to a domain [38]. The findings refer to discovery of new talents and engaging individuals who work in the processes that are to be improved. Here, the domain-or operative context-of the individual is taken as given, and learning about lean and energy is achieved through the professional education program. That is, lean energy helps individuals interpret their domain; that is, where their expertise lies. An alternative approach would be to bring in external consultants with expertise in lean energy to analyze domain or operative contexts that are not well known to them. Interpretation also moves beyond the individual and to a group level through such means as a lean game in the teaching program, but also through notions by interviewees such as "teamwork rather than cowboys" (work in a team rather than alone) in the organization.

\subsection{Integrating}

Integrating refers to a coherent and collective action that requires shared understanding and coordinated actions towards mutual adjustments [38]. Creating a dialogue and taking actions are key characteristics herein. Through this process, the learning process takes place at a group rather than individual level and the integration refers both to the combination of lean and energy, but perhaps more importantly, to connecting these principles into practice through concrete improvement actions. Herein, the professional education program plays an apparent role as a mechanism for learning, both regarding the conceptual combination of lean and energy, but also by creating positive conditions for improvement actions through such means as the participants' home assignments. This acquired knowledge enables effective decision making and implementation of corporate energy efficiency goals in day-to-day practices in operations through a shared understanding and commitment [44,45]. In terms of assigning education - in our case, professional education-a certain role in sustainable development of operational processes is in line with the current body of knowledge. For example, Byrne et al. [46] identified resources, technology, values/ethics/inter and intragenerational equity and transdisciplinary, systems and complex thinking as the most important sustainability-related competencies that need to be developed in sustainability education. According to Walker et al. [47], a sustainability course for practitioners should (1) use live social theme-based projects or work experience, (2) develop critical skills and engage in real-work problem solving, (3) take a problem-based learning approach through team work in co-operation with organizations, (4) use senior practitioner guest lectures who provide examples of their sustainability and cost-saving achievements, and (5) take a systems theory approach. As presented above, Lean energy closely resembles these five characteristics.

As lean was intended to become a practice in the participating organizations, the design of the professional education program followed the logic of Lean [2]. The topics covered provided tools from energy technology to identify energy consumption and, when combined with concepts such as value stream mapping from lean, the participants could individually conduct a trial analysis of energy consumption and waste in their organization. To some extent, this develops sustainability key competences, such as problem-solving skills and the ability to collaborate successfully with experts, through "real-world learning opportunities" proposed by Brundiers et al. [48]. However, this activity primarily resulted in personal learning rather than impacting on the individuals' own organizations.

\subsection{Institutionalizing}

Institutionalizing refers to learned behavior from individuals and groups that is now embedded in the organization's systems, procedures and routines, ensuring that significant actions occur [38]. One example of such learned behavior is an outline of a "working model" for lean energy developed 
in one of the studied organizations. Two other characteristics of institutionalization of lean energy are the practice of change management and, more fundamentally, the idea that everyone becomes a change agent.

From learning behavior to practicing change management: The personal influence from the course, as well as knowledge and lessons learned for the individual participants, reconcile with the movement from level two to three, where actions for improvement become more regular. At this level, learning can be regarded as individual and personal, and attempts to create a group effort are limited to discrete projects. Acquiring new knowledge externally through "substantial cooperation" is seen as necessary to "secure successful efforts" [34].

Moving to a higher level of maturity, towards continuous actions, entails firmer integration of lean and energy efficiency in various principles, practices and tools, and an organization-wide effort. To reach this level, the organization must ensure that a number of individuals receive the same education, arrange for a series of improvement projects in different processes and/or at different locations, and arrange for a follow-up and sharing of experiences. Teamwork is seen as necessary to promote actions on sustainability [37], and both quality management and lean do inherently lend principles to such efforts. Here, practices are not local but shared, and built upon a learning organization, synergies across locations, continuity, and integration of energy efficiency improvement with other efforts. As such, energy provides depth to the sustainability approach of the organization, but the combination of lean and energy provides breadth through a "synergizing power by uniting people" [27].

Integrate across locations through a "working model": The fact that this study was conducted over a period of time made it possible to follow the development of the course participants and their organizations. Here it became apparent that whilst the course program was important to both conceptually integrate lean and energy and to internalize this through quality management principles, the developmental potential was regarded as individual and local. By releasing the potential at a wider organizational scale and bringing this into continuous improvement effort at organizational level, the focal organization had to take over responsibility and transfer ownership of the program to the organization. While transferring the knowledge from individuals to the organization and through creating sufficient knowledge across the organization, a maturity process takes place. In this process, sustainability competencies precede from "specialization" of separate competences in "lean" and "green" operations towards "integration" of competencies in "lean green", as proposed by Siva et al. [13].

Everyone becomes a change agent: A lot of the literature on lean and green refers to the importance of employee engagement and, when infused with quality management, a team-level effort is brought into play. However, our findings show that there needs to be a coordinated effort at a high organizational level in order to coordinate and learn from teams at different locations. The positive effects of cross-functional executive and worker involvement in alignment of strategic goals and behavior at different hierarchical levels and functions have also been previously suggested. More specifically, previous research suggests that organizational aspects foster internal and external consistency of sustainability strategies across the organization [49] and that cross-functional employee involvement can positively affect the strategic alignment of operations practice (such as lean) with environmental and social goals and practices [50].

\section{Conclusions}

The integration of lean and energy efficiency can be effectively explained through and stimulated by lean management and its underlying principles of quality management such as teamwork and continuous improvement. One step to mobilize the integration of lean and energy efficiency is by acquiring competence externally through professional education and training of employees that are, or can be made, responsible for improvement efforts of energy consuming processes. A key feature of the learning in the program investigated is not only to educate about lean (that is, content), but also follow the logic of lean during the course (for example, by conducting energy mapping and waste analysis by using value stream mapping). In this way, the participants experience Lean energy as a process and 
have the opportunity to receive feedback from both peers and lecturers. At first, this leads to individual learning and personalized knowledge. However, to create actions that have impact on sustainable development of the organization Lean energy needs to be scaled up, guided by principles of people, perspectives, and practices. To understand the extent to which lean energy, as investigated here, can bring organizations from individual learning to a more comprehensive organizational renewal, this paper relates the lean energy practice to four learning processes. Whereas intuiting and interpreting refer to the levels of individuals and teams, integrating and in particular institutionalizing bring lean energy towards a comprehensive solution at multiple locations, where, in principle, everyone becomes a change agent. Thus, it is concluded that the combination of lean and energy has a synergistic potential. However, to create positive conditions to release this potential of this, two more conditions are beneficial, namely professional education and organizational scale-up. Higher education can be considered as a part of the institutional environment of the organizations studied and acts through the lean energy professional education program as an important initiator for the conceptual integration of lean and energy, and to mobilize individual and group learning. However, it is the responsibility of the management of the organizations studied to use these employees as change agents to achieve more organization-wide improvements.

Based on the focus and limitation of this study, two venues of further research are proposed. First, while lean is directly connected to efficiency and economic aspects of sustainability, and the findings of the present study suggest the importance of social interactions and engagement of employees, a comprehensive study considering integration of lean in all three dimensions of sustainability simultaneously is necessary. Second, the conditions and learning processes outlined above need to be analyzed further in relation to current maturity models within the lean and green literature [2].

Author Contributions: Á.H. and A.W. outlined the initial study and conducted the first round of analysis. The data collection was lead by A.W., supported by Á.H. and N.T. The conceptualization, discussion and implications were lead by I.G. and Á.H., with support from N.T. on literature in particular. All authors contributed to the writing of the paper.

Funding: This work was supported by the Sustainable Production Initiative and the Production Area of Advance at Chalmers University of Technology and the Swedish Energy Agency. The support is gratefully acknowledged.

Conflicts of Interest: The authors declare no conflict of interest.

\section{References}

1. MacInnis, D.J. A Framework for Conceptual Contributions in Marketing. J. Mark. 2011, 75, $136-154$. [CrossRef]

2. Caldera, H.T.S.; Desha, C.; Dawes, L. Exploring the role of lean thinking in sustainable business practice: A systematic literature. J. Clean. Prod. 2017, 167, 1546-1565. [CrossRef]

3. Siva, V.; Gremyr, I.; Bergquist, B.; Garvare, R.; Zobel, T.; Isaksson, R. The support of Quality Management to sustainable development: A literature review. J. Clean. Prod. 2016, 138, 148-157. [CrossRef]

4. Garza-Reyes, J.A. Lean and Green-A systematic review of the state of the art literature. J. Clean. Prod. 2015, 102, 18-29. [CrossRef]

5. Kleindorfer, P.R.; Singhhal, K.; Van Wassenhove, L.N. Sustainable operations management. Prod. Oper. Manag. 2005, 14, 482-492. [CrossRef]

6. Pampanelli, A.B.; Found, P.; Moura Bernardes, A. A Lean \& Green Model for a production cell. J. Clean. Prod. 2014, 85, 19-30. [CrossRef]

7. Abreu, M.F.; Alves, A.C.; Moreira, F. Lean-Green models for eco-efficient and sustainable production. Energy 2017, 137, 846-853. [CrossRef]

8. Robèrt, K.-H.; Schmidt-Bleek, B.; Aloisi de Larderel, J.; Basile, G.; Jansen, J.L.; Kuehr, R.; Price Thomas, P.; Suzuki, M.; Hawken, P.; Wackernagel, M. Strategic sustainable development-Selection, design and synergies of applied tools. J. Clean. Prod. 2002, 10, 197-214. [CrossRef]

9. Angell, L.C.; Klassen, R.D. Integrating Environmental Issues into the Mainstream: An Agenda for Research in Operations Management. J. Oper. Manag. 1999, 17, 575-598. [CrossRef] 
10. Srivastava, S.K. Green supply-chain management: A state-of-the-art literature Review. Int. J. Manag. Rev. 2007, 9, 53-80. [CrossRef]

11. Maxwell, D.; Van der Vorst, R. Developing sustainable products and services. J. Clean. Prod. 2013, 11, 883-895. [CrossRef]

12. Rusinko, C.A. Using quality management as a bridge to environmental sustainability in organisations. $S A M$ Adv. Manag. J. 2005, 70, 54-60. [CrossRef]

13. Siva, V.; Gremyr, I.; Halldórsson, Á. Organising Sustainability Competencies through Quality Management: Integration or Specialisation. Sustainability 2018, 10, 1326. [CrossRef]

14. Dean, J.W., Jr.; Bowen, D.E. Management theory and total quality: Improving research and practice through theory development. Acad. Manag. Rev. 1994, 19, 392-418. [CrossRef]

15. Modig, N.; Åhlström, P. This Is Lean—Resolving the Efficiency Paradox; Rheologica Publishing: Stockholm, Sweden, 2013.

16. Holbeche, L. Motivating People in Lean Organizations; Butterworth-Heinemann: Oxford, UK, 1997.

17. Ricondo, I.; Viles, E. Six Sigma and its link to TQM, BPR, Lean and the learning organization. Int. J. Six Sigma Compet. Advant. 2005, 1, 323-354. [CrossRef]

18. Spector, R.E. How constraints management enhances Lean and Six Sigma. Supply Chain Manag. Rev. 2006, $10,42-47$.

19. Näslund, D. Lean, Six Sigma and Lean Sigma: Fads or real process improvement methods? Bus. Process. Manag. J. 2008, 14, 269-287. [CrossRef]

20. Womack, J.P.; Jones, D.T.; Roos, D. The Machine That Changed the World; Rawson Associates Scribner: New York, NY, USA, 1990.

21. Dües, C.M.; Tan, K.H.H.; Lim, M. Green as the new Lean: How to use Lean practices as a catalyst to greening your supply chain. J. Clean. Prod. 2013, 40, 93-100. [CrossRef]

22. Verrier, B.; Rose, B.; Caillaud, E.; Remita, H. Combining organizational performance with sustainable development issues: The Lean and Green project benchmarking repository. J. Clean. Prod. 2014, 85, 83-93. [CrossRef]

23. Azevedo, S.G.; Carvalhho, H.; Duarte, S.; Cruz-Machado, V. Influence of green and lean upstream supply chain management practices on business sustainability. IEEE Trans. Eng. Manag. 2012, 59, 753-765. [CrossRef]

24. Piercy, N.; Rich, N. The relationship between lean operations and sustainable operations. Int. J. Oper. Prod. Manag. 2015, 35, 282-315. [CrossRef]

25. Aguado, S.; Alvarez, R.; Domingo, R. Model of efficient and sustainable improvements in a lean production system through processes of environmental innovation. J. Clean. Prod. 2013, 47, 141-148. [CrossRef]

26. Alves, J.R.X.; Alves, J.M. Production management model integrating the principles of lean manufacturing and sustainability supported by the cultural transformation of a company. Int. J. Prod. Res. 2015, 53, 5320-5333. [CrossRef]

27. Wong, W.P.; Wong, K.Y. Synergizing an ecosphere of lean for sustainable operations. J. Clean. Prod. 2014, 85, 51-66. [CrossRef]

28. Baumgartner, R.J.; Rauter, R. Strategic perspectives of corporate sustainability management to develop a sustainable organization. J. Clean. Prod. 2017, 140, 81-92. [CrossRef]

29. May, G.; Stahl, B.; Taisch, M. Energy management in manufacturing: Toward eco-factories of the future-A focus group study. Appl. Energy 2016, 164, 628-638. [CrossRef]

30. Koh, S.C.L.; Morris, J.; Ebrahimi, S.M.; Obayi, R. Integrated resource efficiency: Measurement and management. Int. J. Oper. Prod. Manag. 2016, 36, 1576-1600. [CrossRef]

31. Abdul Rashid, S.H.; Evans, S.; Longhurst, P. A comparison of four sustainable manufacturing strategies. Int. J. Sustain. Eng. 2018, 1, 214-229. [CrossRef]

32. Miltenburg, J. Manufacturing Strategy: How to Formulate and Implement a Winning Plan; Productivity Press: New York, NY, USA, 2005.

33. Aughney, N.; O'Donnell, G.E. The energy saving opportunity in targeting non-value added manufacturing activities-A structured approach. J. Clean. Prod. 2015, 86, 191-200. [CrossRef]

34. Karatzoglou, B. An in-depth literature review of the evolving roles and contributions of universities to Education for Sustainable Development. J. Clean. Prod. 2013, 49, 44-53. [CrossRef] 
35. Aleixo, A.M.; Leal, S.; Azeiteiro, U.M. Conceptualization of sustainable higher education institutions, roles, barriers, and challenges for sustainability: An exploratory study in Portugal. J. Clean. Prod. 2018, 172, 1664-1673. [CrossRef]

36. Molderez, E.; Fonseca, E. The efficacy of real-world experiences and service learning for fostering competences for sustainable development in higher education. J. Clean. Prod. 2018, 172, 4397-4410. [CrossRef]

37. Kay, M.J.; Kay, S.A.; Tuininga, A.R. Green teams: A collaborative training model. J. Clean. Prod. 2018, 176, 909-919. [CrossRef]

38. Crossan, M.M.; Lane, H.W.; White, R.E. An Organizational Learning Framework: From Intuition to Institution. Acad. Manag. Rev. 1999, 24, 522-537. [CrossRef]

39. Flick, U. An Introduction to Qualitative Research, 5th ed.; Sage: London, UK, 2014.

40. Edmondson, A.; McManus, S. Methodological Fit in Management Field Research. Acad. Manag. Rev. 2007, 32, 1155-1179. [CrossRef]

41. Yin, R.K. Case Study Research: Design and Methods; Sage: Thousand Oaks, CA, USA, 2003.

42. Van de Ven, A. Engaged Scholarship: A Guide for Organizational and Social Research; Oxford University Press: New York, NY, USA, 2007.

43. Barney, J.B. How a Firm's Capabilities Affect Boundary Decision. Sloan Manag. Rev. 1999, 40, $137-145$.

44. Boyer, K.K.; McDermott, C. Strategic consensus in operations strategy. J. Oper. Manag. 1999, 17, $289-305$. [CrossRef]

45. Kellermanns, F.W.; Walter, J.; Lechner, C.; Floyd, S.W. The lack of consensus about strategic consensus: Advancing theory and research. J. Manag. 2005, 31, 719-737. [CrossRef]

46. Byrne, E.P.; Desha, C.D.; Fitzpatrick, J.J.; Hargroves, K. Exploring sustainability themes in engineering accreditation and curricula. Int. J. Sustain. High. Educ. 2013, 14, 384-403. [CrossRef]

47. Walker, H.L.; Gough, S.; Bakker, E.F.; Knight, L.A.; McBain, D. Greening operations management: An online sustainable procurement course for practitioners. J. Manag. Educ. 2009, 33, 348-371. [CrossRef]

48. Brundiers, K.; Wiek, A.; Redman, C.L. Real-world learning opportunities in sustainability: From classroom into the real world. Int. J. Sustain. High. Educ. 2010, 11, 308-324. [CrossRef]

49. Epstein, M.J. Making Sustainability Work; Berrett-Koehler Publisher Inc.: San Francisco, CA, USA, 2008.

50. Longoni, A.; Cagliano, R. Cross-functional executive involvement and worker involvement in lean manufacturing and sustainability alignment. Int. J. Oper. Prod. Manag. 2015, 35, 1332-1358. [CrossRef] 